\title{
REVIEW
}

\section{Mechanisms for sex differences in energy homeostasis}

\author{
Chunmei Wang ${ }^{1}$ and Yong $\mathrm{Xu}^{1,2}$ \\ 1Department of Pediatrics, Children's Nutrition Research Center, Baylor College of Medicine, Houston, Texas, USA \\ 2Department of Molecular and Cellular Biology, Baylor College of Medicine, Houston, Texas, USA
}

Correspondence should be addressed to Y Xu: yongx@bcm.edu

\begin{abstract}
Sex differences exist in the regulation of energy homeostasis. Better understanding of the underlying mechanisms for sexual dimorphism in energy balance may facilitate development of gender-specific therapies for human diseases, e.g. obesity. Multiple organs, including the brain, liver, fat and muscle, play important roles in the regulations of feeding behavior, energy expenditure and physical activity, which therefore contribute to the maintenance of energy balance. It has been increasingly appreciated that this multi-organ system is under different regulations in male vs female animals. Much of effort has been focused on roles of sex hormones (including androgens, estrogens and progesterone) and sex chromosomes in this sex-specific regulation of energy balance. Emerging evidence also indicates that other factors (not sex hormones/receptors and not encoded by the sex chromosomes) exist to regulate energy homeostasis differentially in males vs females. In this review, we summarize factors and signals that have been shown to regulate energy homeostasis in a sexually dimorphic fashion and propose a framework where these factors and signals may be integrated to mediate sex differences in energy homeostasis.
\end{abstract}
Key Words
- hormone action
- obesity
- receptors
- sex steroids

\section{Introduction}

Obesity, resulting from imbalance of energy homeostasis, is now recognized as a serious global health problem, due to its high prevalence and strong association with hypertension, coronary heart disease, stroke and other metabolic disorders. A clear sexual dimorphism exists in the regulation of feeding behavior and energy homeostasis in rodents (Shi et al. 2009, Sugiyama \& Agellon 2012). For example, total daily energy intake in male rats is higher than that in females, even when corrected by their larger lean body mass and metabolic rate (Woodward \& Emery 1989). In addition, high-fat diet (HFD) feeding leads to larger body weight gain in male rats/mice than in female counterparts (Grove et al. 2010, Benz et al. 2012, Stubbins et al. 2012, Yang et al. 2014, Morselli et al. 2016, Dorfman et al. 2017). However, the mechanisms for this sexual dimorphism remain elusive, and better understanding of this fundamental sex difference in energy homeostasis will no doubt benefit our current combat against obesity pandemics.

Males and females are obviously different in the circulating levels of sex hormones and the sex chromosomes their cells carry. Thus, these two categories of factors have been generally thought to be major contributors to the sexual dimorphism in obesity. In this review, we will discuss the functions of sex hormones and sex chromosomes in the context of body weight 
control. In addition, we will also discuss additional factors, which do not belong to these two categories, as additional contributors to the sex dimorphism of energy homeostasis.

\section{Sex hormones}

Androgens are described as male sex hormones and estrogens are described as female sex hormones (Chan \& O'Malley 1976). The most important biologically relevant forms of estrogens and androgens are 17 $\beta$-estradiol (E2) and testosterone, respectively. Both males and females have these hormones to varying degrees. Androgens are produced in male testis and female ovary. Androgens, mainly testosterone and androstenedione, can be converted to estrogens by aromatase (Jarvie \& Hentges 2012). Thus, even in males, despite the low circulating levels of estrogens, estrogens can be produced through local aromatization using circulating testosterone as a substrate. Tissues that express aromatase include not only the gonads, but also the breast, brain, muscle, bone and adipose tissue (Nelson \& Bulun 2001, Simpson 2003, Simpson et al. 2005). Another major female sex hormone is progesterone, which can also be synthesized by the adrenal glands (Wittmann et al. 2013, Johnston et al. 2015) and nervous tissue, especially in the brain (Schumacher et al. 2004). Classically, androgens, estrogens and progesterone can bind to their nuclear receptors namely androgen receptors (ARs), estrogen receptors (ERs) and progesterone receptors, respectively, and these receptors function as transcription factors to regulate gene expression (Yang \& Shah 2014). Accumulating evidence also indicates that these sex hormones can bind to membrane receptors and exert rapid signal transduction effects in target cells (Mamounis et al. 2014). As outlined below, these sex hormones and their receptors contribute to the regulation of energy balance with complex mechanisms.

\section{Estrogens}

\section{Ligand}

It is well documented that estrogens play an essential role in preventing body weight gain in females. For example, the withdrawal of endogenous estrogens by ovariectomy (OVX) in female animals leads to body weight gain and hyperadiposity, and these obese phenotypes can be prevented by E2 treatment but not by progesterone (Drewett 1973, Schwartz \& Wade 1981, Geary et al. 2001, Wallen et al. 2001, Roesch 2006, Rogers et al. 2009). Since E2 can be produced via conversion from testosterone by the aromatase, aromatase-knockout mice represent a good model to examine functions of endogenous E2 not only in female but also in male animals. Female aromatase-knockout mice show increased body weight from 3 months of age, while male mutant mice show late-onset obesity one year later (Jones et al. 2000). Both male and female aromatase-knockout mice show increased gonadal and infrarenal fat pad compared to control littermates (Jones et al. 2000). This increased adiposity is associated with reduced spontaneous physical activity levels, reduced glucose oxidation and a decrease in lean body mass (Jones et al. 2000). These findings indicate that endogenous E2 prevents obesity in both sexes.

\section{$E R \alpha$}

Estrogen receptors include estrogen receptor- $\alpha(E R \alpha)$, estrogen receptor- $\beta$ (ER $\beta)$ and $G$ protein-coupled receptor 30 (GPR30). In particular, ER $\alpha$ is perhaps most studied in the context of energy balance. Humans or mice with mutations in the $\mathrm{ER} \alpha$ (Esr1) gene are obese (Heine et al. 2000, Okura et al. 2003). Further, deletion of ER $\alpha$ in mice blocks the anorexigenic effects of E2 treatment (Geary et al. 2001). Early studies showed that microinjections of E2 into various brain regions change animal's feeding behavior (Palmer \& Gray 1986, Butera \& Beikirch 1989), suggesting that $\mathrm{ER} \alpha$ expressed in the brain is important for the regulation of food intake. This notion was further supported by observations from various genetic mouse models. For example, we crossed mice carrying loxPflanked ER $\alpha$ alleles (Esr1fl/f) (Feng et al. 2007) to the NestinCre transgenic mice (Bruning et al. 2000) to produce mice lacking $\mathrm{ER} \alpha$ only in the brain (Xu et al. 2011). These female mutant mice develop obesity, characteristic of increased body weight and body fat. Obesity in these mice is associated with hyperphagia, decreased energy expenditure and decreased physical activity, which may all contribute to the development of obesity ( $\mathrm{Xu}$ et al. 2011). Notably, female mice lacking $E R \alpha$ in the brain display significantly elevated $\mathrm{E} 2$ in the circulation (Xu et al. 2011), presumably due to the impaired negative feedback regulation by estrogens. Given that these mice develop robust obese phenotypes despite the higher E2 in the circulation, these observations argue that compared to $\mathrm{ER} \alpha$ expressed in peripheral tissues, brain $\mathrm{ER} \alpha$ plays predominant roles in the regulation of energy balance. Notably, male mice lacking ER $\alpha$ in the brain also develop modest obesity, indicating that brain $\mathrm{ER} \alpha$ is required to prevent body weight gain in males (Xu et al. 2011). 
$\mathrm{ER} \alpha$ is abundantly expressed in multiple brain regions that are implicated in the regulation of feeding behavior. These include the arcuate nucleus (ARH), the ventromedial hypothalamic nucleus $(\mathrm{VMH})$, the nucleus of the solitary tract (NTS), the medial amygdala (MeA), the dorsal Raphe nuclei (DRN), and the medial preoptic area (MPOA) (Merchenthaler et al. 2004). Interestingly, while many of these brain regions, e.g. ARH, VMH and MPOA, in female brains express more abundant ER $\alpha$ than in male brains (Cao \& Patisaul 2011; Kyi-Tha-Thu, et al. 2015), a few other regions in male brains, including the MeA, show higher ER $\alpha$ expression than in females ( $\mathrm{Xu}$ et al. 2015). In particular, about $20-30 \%$ proopiomelanocortin (POMC) neurons in the ARH co-express ERo (Miller et al. 1995, de Souza et al. 2011, Xu et al. 2011). E2 can increase excitatory synaptic inputs onto ARH POMC neurons and activate these neurons (Gao et al. 2007, Malyala et al. 2008, Saito et al. 2015). Female mice lacking ER $\alpha$ only in POMC neurons develop hyperphagia and modest body weight gain (Xu et al. 2011). In addition, E2-induced anorexigenic effects are blunted in these mutant female mice lacking ER $\alpha$ only in POMC neurons (Zhu et al. 2015). Notably, male mice lacking ER $\alpha$ in POMC neurons do not have any feeding phenotypes (Xu et al. 2011). Another hypothalamic ER $\alpha$ population with sexually dimorphic functions is that in the VMH. Martinez de Morentin et al. reported that injections of $\mathrm{E} 2$ into the $\mathrm{VMH}$ promote BAT-mediated thermogenesis in female rats (Martinez de Morentin et al. 2014). Correa et al. developed a mouse model with loss of $26 \%$ of ER $\alpha$-positive neurons in the $\mathrm{VMH}$; this loss of ER $\alpha$-positive neurons cause profound obesity only in females but not in males (Correa et al. 2015). Consistently, genetic deletion of ER $\alpha$ specifically in the VMH leads to female obesity, but does not affect male energy balance in rodents (Musatov et al. 2007, Xu et al. 2011). Collectively, these observations indicate that ER $\alpha$ in POMC neurons and VMH neurons contributes to the sex differences in body weight balance.

Other hypothalamic ER $\alpha$ populations may also be involved in body weight control. For example, Santollo et al. reported that microinjections of E2 into the MPOA decreases food intake in female rats (Santollo et al. 2011). Further, earlier studies showed that E2 implanted in the paraventricular nucleus of the hypothalamus (PVH) decreases food intake and body weight in OVX female rats (Butera \& Beikirch 1989). Additionally, the anorexigenic effects of subcutaneous E2 were blunted in female rats with PVH lesions (Butera et al. 1992). However, subsequent studies failed to reproduce these phenotypes in female rats with PVH implants (Hrupka et al. 2002). In addition, it needs to be pointed out that the PVH expresses low levels of ER $\alpha$ but high levels of ER $\beta$ (Merchenthaler et al. 2004). Thus, the functions of ERo in the MPOA and the $\mathrm{PVH}$ warrant further validation with genetic models.

ER $\alpha$ is also present in the hindbrain, including the NTS (Osterlund et al. 1998, Merchenthaler et al. 2004, Schlenker \& Hansen 2006). Treatment of E2 in WT female mice suppresses food intake and potentiates CCK-induced satiation, which are accompanied by increased activity in NTS neurons (Geary et al. 2001, Asarian \& Geary 2007). Interestingly, these responses are all abolished in female mice lacking ER $\alpha$ (Geary et al. 2001, Asarian \& Geary 2007). ER $\alpha$ is abundantly expressed in the DRN (Merchenthaler et al. 2004), and the majority of these ERo-positive neurons in the DRN are 5-HT neurons (Cao et al. 2014). E2 increases neural activities of DRN 5-HT neurons via an ER $\alpha$-dependent mechanism (Robichaud \& Debonnel 2005, Dalmasso et al. 2011, Cao et al. 2014). Santollo et al. reported that microinjections of E2 into the DRN decreases food intake in female rats (Santollo et al. 2011). Female mice lacking ER $\alpha$ only in 5-HT neurons are resistant to E2's effects to suppress binge-like eating (Cao et al. 2014), a type of eating behavior that is not driven by hunger but rather than by rewards or hedonic cues. Collectively, ER $\alpha$ in the NTS and DRN mediates the anorexigenic effects of E2 in females, while functions of these ER $\alpha$ populations in male animals remain unknown.

However, it is clear that actions of ER $\alpha$ also prevent obesity in males. For example, ER $\alpha$ gene deficiency results in obesity in male mice (Heine et al. 2000, Callewaert et al. 2009) and in men (Smith et al. 1994, Grumbach \& Auchus 1999). In addition, administration of $\mathrm{E} 2$ or its analogs reduces body weight in male mice (Gao et al. 2007, Finan et al. 2012). Both male and female aromatase-knockout mice develop obesity (Jones et al. 2000). Notably, abundant aromatase is expressed in a few brain regions, including the MeA (Wu et al. 2009), which makes it possible that $\mathrm{ER} \alpha$ in these male brain regions could be exposed to high levels of E2 despite the lack of circulating estrogens. Indeed, loss of ERo in the MeA causes obesity not only in female mice, but also in male mice (Xu et al. 2015). Thus, we speculate that ER $\alpha$ populations in brain regions with aromatase activity may play sexually monomorphic roles in the regulation of energy balance, while ER $\alpha$ in brain regions devoid of aromatase activity contribute to the sex differences in body weight balance.

The role of ER $\alpha$ in the peripheral tissues has been extensively reviewed before (Mauvais-Jarvis et al. 2013). The deletion of ER $\alpha$ from the liver does not affect body weight fed with chow or HFD in either male or female 
mice (Matic et al. 2013). Loss of ERo in the muscle causes obesity in female mice, associated with decreased energy expenditure and physical activity without changes in food intake (Ribas et al. 2010), while effects of such deletion in male mice were not reported. Deletion of ER $\alpha$ in adipocytes causes obesity in female mice but not in male mice (Davis et al. 2014). Together, the current literature indicates that ERo in some regions of the brain and in fat contributes to the maintenance of energy homeostasis in a sexually dimorphic fashion, although its effects in males still warrant further investigations. However, ER $\alpha$ in brain regions with enriched aromatase activity (e.g. the MeA) regulates energy balance in both sexes.

\section{Other ERs}

Compared to ER $\alpha, E R \beta$, another classic ER, has received less attention at least in the context of body weight balance. An earlier study by Ohlsson et al. reported that chow-fed mice (both male and female) with global deficiency in ER $\beta$ show normal body weight and fat mass compared to WT mice (Ohlsson et al. 2000). Consistent with this, both Santollo et al. (Santollo et al. 2007) and Roesch (Roesch 2006) found that an ER $\beta$ agonist, diarylpropionitrile (DPN), has no effect on food intake and body weight in chow-fed OVX female rats, while PPT (the ER $\alpha$ agonist) at similar doses can significantly reduce food intake and body weight. While these earlier studies suggest a minor role of ER $\beta$ in body weight control in chow-fed animals, ForystLudwig et al. demonstrated that female ER $\beta$-knockout mice, when fed on a HFD, developed obesity compared to HFD-fed WT mice, which is associated with normal food intake, but increased energy expenditure and decreased fat oxidation (Foryst-Ludwig et al. 2008). However, it has not been reported whether male mice lacking ER $\beta$ also show similar obese phenotypes. Certainly, the ER $\beta$-mediated control of energy homeostasis in difference sexes warrants further investigations.

GPR30 (also known as GPER) is a G proteincoupled estrogen receptor, bound to the cell membrane (Thomas et al. 2005). Body weight phenotypes among several independent GPR30-knockout mouse lines are controversial. For example, both Haas et al. (2009) and Sharma et al. (2013) observed obese phenotypes in male and female GPR30-knockout mice, which were generated by Wang et al. (2008); however, Liu et al. reported no difference in body weight in the same GPR30knockout strain (Liu et al. 2009). Otto et al. constructed an independent GPR30-knockout line and found no obese phenotypes in female mutants (Otto et al. 2009).
Interestingly, another GPR30-knockout line generated by Martensson et al. shows reduced body weight only in females, but not in males (Martensson et al. 2009). More recently, Davis et al. re-characterized Wang's GPR30knockout mice and reported that both male and female mutants are significantly heavier than WT littermates, which appears to depend on reduced energy expenditure independent of physical activity, but not on food intake (Davis et al. 2014). The discrepancy from these studies may be attributed to different strategies to construct the GPR30-knockout alleles, different genetic background that mice were maintained on and/or different facility environment, etc. Further investigations are warranted to confirm THE roles of GPR30 in estrogenic regulation on body weight homeostasis in both sexes.

Collectively, high levels of circulating estrogens prevent obesity in female animals. Many of these estrogenic actions are mediated by multiple ER $\alpha$ populations, which therefore at least partly account for sex differences in body weight. However, ER $\alpha$ in certain brain regions with enriched aromatase activity, e.g. the MeA, also contributes to the maintenance of male energy balance. ER $\beta$ and GPR30 also regulate body weight balance, but their sexspecific functions remain to be further investigated.

\section{Progesterone}

Unlike estrogens, the administration of progesterone alone does not affect food intake, body weight or adiposity in OVX female mice (Toth et al. 2001). However, the anorectic effect of estrogens can be attenuated by concurrent administration of progesterone (Wade 1975, Schwartz \& Wade 1981). In gonadal intact rodents, exogenous progesterone causes increase in body weight and inguinal white adipose tissue mass in female animals but not in male animals, by regulating the endocrine properties of adipocytes (Sarton et al. 2001, Komatsu et al. 2011, Kudo et al. 2014). However, female mice with the global deletion of progesterone receptor do not show any difference in body weight (Rickard et al. 2008). Notably, Klump et al. reported that in cycling women, the tendencies of binge eating are negatively associated with circulating estrogen level but positively associated with progesterone level (Klump et al. 2013, 2014), suggesting that progesterone may promote binge eating. However, administration of progesterone in OVX female rats does not affect binge-like eating behavior (Yu et al. 2011), although it remains debatable whether the binge-like eating behaviors in rodents really simulates human binge eating. Collectively, some evidence exists to 
support an orexigenic effect of progesterone, but further investigations are needed to confirm these effects and to explore the underlying mechanisms.

\section{Androgens}

\section{Ligand}

Androgens are also implicated to regulate male and female energy balance. Most women diagnosed with polycystic ovary syndrome (PCOS) are hyperandrogenemic and higher level of serum androgen is correlated with higher BMI (Dumesic et al. 2016, Yuan et al. 2016, Alexiou et al. 2017). In female animals, chronic treatment of dihydrotestosterone (DHT), a non-aromatizable androgen, promotes visceral adiposity with reduced energy expenditure but normal food intake (Nohara et al. 2014). These effects are associated with reduced POMC neuronal innervations in the hypothalamus (Nohara et al. 2014). Effects of testosterone in males appear to be more complex. Serum testosterone levels are inversely correlated with obesity in men (Jorgensen et al. 1996, Katznelson et al. 1998). Men with lower androgen level showed increased fat mass, which can be reversed by the testosterone administration (Rolf et al. 2002). However, in male castrated adult mice, DHT treatment increases adiposity (Moverare-Skrtic et al. 2006). Consistently, treatment of these male mice with testosterone in the presence of an aromatase inhibitor, but not testosterone alone, induces retroperitoneal fat accumulation (Moverare-Skrtic et al. 2006). Together, these observations demonstrate that in both sexes, DHT promote adiposity, probably via actions on the androgen receptor, while effects of testosterone may be complex due to its direct actions on the androgen receptor combined with indirect effects on ERs.

\section{Androgen receptor}

The role of androgen receptor in body weight control was suggested by an abnormal body weight profile in male mice with global androgen receptor knockout (Sato et al. 2003, Fan et al. 2005, Lin et al. 2005). Interestingly, while young mutant male mice show decreased body weight, aged mutant male mice have increased body weight and adiposity compared to age-matched WT males (Sato et al. 2003, Fan et al. 2005, Lin et al. 2005). Although selective deletion of androgen receptor in the brain (resulting from crosses between synapsin 1-Cre mice and $\operatorname{Ar}^{f / / y}$ ) does not affect body weight in young male mice, such deletion leads to a late-onset obesity (Yu et al. 2013). These observations indicate that brain androgen receptor is required to prevent aging-associated obesity in males. Further characterization of the brain-specific androgen receptor deletion mouse model revealed increased expression of an anorexigenic neuropeptide, agouti-related peptide and impaired insulin sensitivity in the hypothalamus, which presumably contribute to the development of obesity in these mice (Yu et al. 2013). Interestingly, HFD feeding was found to accelerate obesity development in mice with brain-specific androgen receptor deletion, and this phenomenon is associated with a heightened activity of hypothalamic NF-кB and increased expression of proteintyrosine phosphatase 1B (PTP1B) (Yu et al. 2013).

Androgen signaling in the liver also contributes to energy homeostasis, as male mice with deletion of androgen receptor from the liver develop obesity when fed with HFD, but female mutants do not (Lin et al. 2008). Deletion of the androgen receptor in adipocyte (using the aP2-Cre as a putative fat-specific Cre allele) does not affect adiposity in male mice fed with chow diet (Yu et al. 2008), but this deletion results in increased visceral fat in mice fed with HFD (McInnes et al. 2012). These results suggest that androgen signaling in the adipose tissue protects against HFD-induced visceral obesity in males. However, the aP2-Cre used for the deletion of androgen receptor may also cause deletion of the receptor in the brain (Mullican et al. 2013). Thus, the effects of the androgen receptor in the fat need to be further validated. The deletion of the androgen receptor in the muscle decreases the weight of both fat mass and lean mass, and body weight in male mice, despite normal food intake (Ophoff et al. 2009). These indicate that the androgen signaling in the muscle is essential for the masculinization of energy homeostasis in males. Thus, effects of the androgen receptor in male animals are tissue specific. While its actions in the brain, liver and adiposity function to prevent male mice from obesity, its actions in the muscle promote growth of both lean mass and adiposity. Notably, except for liver-specific deletion, female phenotypes in mice lacking androgen receptor globally or in specific tissues were not reported in these studies. However, Fagman et al. reported that global deletion of androgen receptor in female mice on an apolipoprotein E (ApoE)-deficient background are prone to diet-induced obesity compared to ApoE-deficient female mice (Fagman et al. 2015). While these results suggest potential anti-obesity actions of androgen receptor in females, these effects need to be further confirmed in animals with normal apoE functions. 


\section{Developmental programming}

The structure and functions of many organs that regulate energy balance, e.g. the brain, are immature at birth (Markakis 2002). In rodent brains, the majority of neural circuits do not fully develop till about postnatal day 21 (Grove \& Smith 2003, Rinaman 2006, 2007). After weaning, the brain still undergoes substantial remodeling (McNay et al. 2011). Events (e.g. nutrient and hormone milieu) during the perinatal window have profound effects on the development of neural circuits controlling body weight and program energy balance later in life (Remmers \& Delemarre-van de Waal 2011). For example, the placenta undergoes adaptations in response to maternal diet and metabolic status to alter fetal nutrient supply, which contributes to the developmental programming of offspring (Gabory et al. 2013, Tarrade et al. 2015). This placental programming effect shows sexual dimorphism (Tarrade et al. 2015). Male placenta decreases size in response to maternal high salt or high-fat intake, which is associated with increased inflammation in the placenta and increased fetal exposure to free fatty acids and glucose. In contrast, female placenta is only affected by maternal high-fat intake but is resistant to high salt stress (Reynolds et al. 2015). In addition, it has been reported in mice that maternal high-fat feeding during lactation period predisposes the male offspring for obesity and impaired glucose homeostasis, which is associated with an impairment of POMC neuron-originated neural circuitry. Strikingly, these effects are not seen in female offspring (Vogt et al. 2014). While mechanisms for this sex difference is not clear, sex hormones have been implicated to regulate development of the brain to program energy balance. For example, immediately after birth, male rodents experience a transient testosterone surge in the circulation associated with a concurrent testosterone surge detected in the hypothalamus (Rhoda et al. 1984). Interestingly, hypothalamic estrogen levels also increase at birth in males (Rhoda et al. 1984), presumably due to aromatization of testosterone. Estrogens are also detectable in female hypothalamus at birth although their levels are lower than those in males during the neonatal period (Amateau et al. 2004). This neonatal surge of sex hormones may program the long-term regulations of energy balance in both sexes. For example, administration of testosterone in male and female rat pups leads to changes in structures and excitability of hypothalamic neurons (Matsumoto \& Arai 1980). Further, neonatal exposure to excess testosterone renders a long-term obese phenotype in female mice, characteristic of increased energy intake and increased visceral adiposity during the adulthood (Nohara et al. 2011, 2013b). These are associated with reduced leptin sensitivity, reduced expression of POMC mRNAs and POMC neuron innervations in the hypothalamus, which may contribute to obesity (Nohara et al. 2011). In males, neonatal exposure to testosterone leads to an early reduction in lean mass, decreases in locomotor activity, energy expenditure and food intake, but a late onset of hyperadiposity (Nohara et al. 2013a). It is important to note that the reduced leptin sensitivity in females is not recapitulated by neonatal DHT exposure (Nohara et al. 2011), suggesting that this effect of testosterone may be mediated by ERs. Collectively, the current literature suggests robust effects of sex hormones on programming of energy balance during early development. Notably, most of genetic mouse studies so far use animal models with genes (e.g. $E R \alpha, E R \beta$, and $A R$ ) deleted at embryonic stage. Thus, data obtained from these models could not fully distinguish effects of the sex hormones during early development vs adulthood; further investigations using inducible genetic deletion models are warranted to tackle this issue.

\section{Sex chromosomes}

The sex dimorphism in gonadal hormones is ultimately determined by the sex chromosomes. The Sry gene located in the $\mathrm{Y}$ chromosome initiates the differentiation of the testes, which produce androgens and cause the masculinization of male mice (Goodfellow \& Lovell-Badge 1993). Without the Sry gene, ovaries will be developed in the female mice and produce ovary hormones including estrogens and progesterone (Goodfellow \& Lovell-Badge 1993). To evaluate the pure effect of sex chromosomes, the Sry gene was deleted from the $\mathrm{Y}$ chromosome to generate $\mathrm{XY}$ mice with ovaries, and translocated to a non-sex chromosome to generate $\mathrm{XX}$ mice with testes, together with $\mathrm{XX}$ ovary mice and $\mathrm{XY}$ testis mice. These 'four core genotypes' mouse model were used to distinguish the effects between gonadal sex (testes or ovaries) and sex chromosomes (XX or XY) (De Vries et al. 2002). Karen Reue's group found that gonadal males (XX testis and $\mathrm{XY}$ testis) are heavier than gonadal females (XX ovary and $\mathrm{XY}$ ovary) in the gonad-intact adult mice, indicating that physiologically sex hormones are dominant in the regulation of sex dimorphism of energy homeostasis. However, the body weight difference among the four groups of mice disappeared 1 month after the gonadectomy, and XX mice (XX ovary and XX testis) gradually become heavier than $\mathrm{XY}$ mice (XY ovary and 
XY testis) 2-10 months after the gonadectomy, associated with increased fat mass, increased daylight time feeding and decreased lipid oxidation (Chen et al. 2012, Reue 2017). They also found that $X X$ and $X X Y$ mice are much heavier than $\mathrm{XO}$ and $\mathrm{XY}$ mice, further supporting an important role of the $\mathrm{X}$ chromosome dosage in the regulation of energy balance (Chen et al. 2012, Reue 2017).

Thus, the $\mathrm{X}$ chromosome dosage is a risk factor for obesity, with one extra X chromosome instead of Y chromosome causing body weight gain (Reue 2017). Notably, XX mice are reported to have lower aromatase expression in the brain than XY mice, independent of gonadal sex (Cisternas et al. 2015), raising a possibility that the obesity seen in XX mice may be due to decreased brain estrogen bioavailability. In addition, the inactivation of one of the two X chromosomes in XX cells during early development silences most genes on the $\mathrm{X}$ chromosome, but some $\mathrm{X}$-linked genes escape this process and cause a higher dose in females than males (Chen et al. 2012, Pessia et al. 2012, Reue 2017). Some of the X-linked 'escape' genes, e.g. Eif2s $3 x, K d m 6 a, D d x 3 x, K d m 5 c, U s p 9 x$ and Uba1, have been validated to be expressed at higher levels in XX fat mass than XY gonadal fat in gonadectomized mice (Chen et al. 2012). However, whether these genes are responsible for the $\mathrm{X}$ chromosome's regulation on energy homeostasis needs to be further studied.

In parallel, a few other X-linked genes have been implicated in the regulation of energy balance. One such example is the gene encoding the androgen receptor, as we have discussed. Another well-studied X-linked gene is O-GlcNAc transferase $(O g t)$, which catalyzes the posttranslational modification of proteins by O-GlcNAc and is regulated by nutrient access. Loss of OGT in orexigenic AgRP neurons inhibits neural activity of these neurons and leads to lean phenotypes in both male and female mice (Ruan et al. 2014). On the other hand, loss of OGT in glutamatergic neurons causes robust obesity in male mice associated with hyperphagia, and these phenotypes can be rescued by restoration of OGT only in PVH neurons that are largely anorexigenic (Lagerlof et al. 2016). Female mice carrying the same mutation were not characterized in this study (Lagerlof et al. 2016). Nevertheless, functions of OGT appear to be site specific, promoting weight gain in AgRP neurons but preventing obesity in PVH neurons, but its sex-specific role needs to be further characterized.

5-HT 2C receptor (5-HT2CR), encoded by an X-linked gene $(\mathrm{Ht} 2 \mathrm{cr}$ ), also plays essential roles in preventing obesity (Tecott et al. 1995). Male mice with global deficiency of 5-HT2CR develop a late-onset hyperphagic obesity, which can be exacerbated by HFD feeding (Tecott et al. 1995, Nonogaki et al. 1998). 5-HT and its analogs, e.g. d-fenfluramine, have been shown to suppress food intake in animals, and these effects are largely mediated via the 5 -HT2CR expressed by POMC neurons in male animals (Xu et al. 2008, Berglund et al. 2013). In addition, the 5-HT2CR expressed by dopamine neurons mediates 5 -HT actions to inhibit binge-like eating in male mice $(\mathrm{Xu}$ et al. 2017). Indeed, a selective agonist of the 5-HT2CR, lorcaserin, was approved by FDA as an anti-obesity medicine. Mechanisms for 5-HT2CR's effects on appetite control involve its actions to activate the transient receptor potential channel 5 (TRPC5), which leads to depolarization of POMC neurons (Gao et al. 2017). Interestingly, TRPC5 is also encoded by the $\mathrm{X}$ chromosome, and it has been shown to mediate actions of multiple hormones on POMC neurons, including estrogens (Qiu et al. 2018), leptin (Qiu et al. 2010, Gao et al. 2017) and insulin (Qiu et al. 2014). Importantly, deletion of TRPC5 in POMC neurons leads to obesity in male mice, which is associated with increased daylight feeding and decreased energy expenditure (Gao et al. 2017). However, effects of both 5-HT2CR and TRPC5 deletion on female energy balance have not been reported.

In summary, the Sry gene on the Y chromosome determines the development of male or female gonads, which influence the circulating sex hormones and therefore energy homeostasis. The $\mathrm{X}$ chromosome also influences the energy balance in a dose-dependent manner. A few X-linked genes have been implicated in energy balance, but their contributions to the sex difference in body weight balance remain to be further investigated. In addition, more $\mathrm{X}$-linked genes may be related to the sexual dimorphism in energy balance, which remain to be identified.

\section{Other factors}

While the majority of the field focus on the functions of sex hormones and sex chromosomal genes, other factors (not sex hormones/receptors and not encoded by the sex chromosomes) may exist to regulate the sex differences in energy homeostasis.

For example, POMC mRNA and POMC neuron projections have been shown to be more abundant in female hypothalamus than in males, corresponding to lower food intake in female mice (Nohara et al. 2011). Further, we recently found that POMC neurons in female mice display higher neural activities compared to male counterparts (Wang et al. 2018). In addition, enhanced POMC mRNAs and neural activity are both attributed to a 
transcription factor, namely TAp63. Strikingly, deletion of TAp63 in POMC neurons confers 'male-like' diet-induced obesity to female mice, but does not affect body weight in male mice (Wang et al. 2018). Importantly, anorexigenic effects of estrogens are not affected by loss of TAp63 in POMC neurons (Wang et al. 2018), suggesting that TAp63 actions are largely independent of the female sex hormone. Notably, the gene encoding TAp63 is located on an autosome. Thus, these results indicate that TAp63 in POMC neurons is one such example that factors, not related to sex hormones/receptors and not on sex chromosomes, could contribute to the sex differences in energy balance. Interestingly, Sirt1, a NAD+-dependent deacetylase (Imai et al. 2000, Michan \& Sinclair 2007), is a known transcriptional target of TAp63 (Su et al. 2012). Deletion of Sirt1 in POMC neurons increases susceptibility to diet-induced obesity specifically in female mice but not in male mice due to reduced energy expenditure, indicating that Sirt1 in POMC neurons plays a sexually dimorphic role in energy homeostasis (Ramadori et al. 2010). Similarly, loss of signal transducer and activator of transcription 3 (STAT3) in POMC neurons leads to modest obesity in female mice but does not affect male mice (Xu et al. 2007). Notably, STAT3 is shown to mediate anorexigenic effects of estrogens (Gao et al. 2007). Thus, the sexually dimorphic functions of STAT3 in POMC neurons may result from different levels of circulating estrogens in males vs females. In contrast, deletion of $\mathrm{GABA}_{\mathrm{B}}$ receptors in POMC neurons results in obesity in the male mice but not female mice fed a HFD, but it is unclear why $\mathrm{GABA}_{\mathrm{B}}$ receptors affect males and females differently (Ito et al. 2013).

In addition to POMC neurons, microglial cells in the hypothalamus also contribute to the sex differences in body weight control. Dorfman et al. recently reported that male mice fed a HFD reduce hypothalamic levels of CX3CL1 (a neuron-released chemokine) and its receptor expressed by microglia, CX3CR1, while the CX3CL1CX3CR1 levels remain normal in the hypothalamus of HFD-fed female mice (Dorfman et al. 2017). Interestingly, female Cx3cr1-knockout mice develop 'male-like' hypothalamic microglial accumulation and activation, associated with increased susceptibility to diet-induced obesity (Dorfman et al. 2017). Conversely, increasing brain CX3CL1 levels in the hypothalamus of male mice converts them to a 'female-like' metabolic phenotype with reduced microglial activation and reduced body weight gain (Dorfman et al. 2017). These data identify the CX3CL1-CX3CR1 signaling in hypothalamic microglia as an important mediator for sex differences in energy balance.

Kisspeptin (Kiss1) and its receptor, GPR54, are key regulators of reproduction (Murphy 2005). Female mice lacking GPR54 develop massive obesity fed with either chow or HFD, associated with increased fat mass and serum leptin level, and decreased energy expenditure but normal food intake (Tolson et al. 2014, 2016). On the other hand, male mice lacking GPR54 have none to minimal phenotypes in energy balance (Tolson et al. 2014, 2016). Thus, the KISS1-GPR54 signaling regulates energy homeostasis in a sexually dimorphic fashion. Notably, since loss of KISS1-GPR54 signaling substantially reduces the circulating levels of testosterone in males and reduces estrogens in females (Seminara et al. 2003, d'Anglemont de Tassigny et al. 2007), the obesity phenotypes observed in GPR54-knockout mice could be at least partially attributed to the altered levels of sex hormones in these mice. Similarly, global deletion of angiotensin II receptor (AT2R) renders female mice more prone to diet-induced obesity with impaired lipid metabolism, but the same mutation does not affect male mice (Samuel et al. 2013). This female-specific obesity is associated with reduced estrogen level in female mutants, which may account for the sexually dimorphic obesity seen in mice lacking AT2R (Samuel et al. 2013).

While many of the aforementioned factors appear to prevent obesity in females, lecithin cholesterol acyltransferase (LCAT) plays an exactly opposite role. LCAT is an enzyme in the regulation of high-density lipoprotein (HDL) metabolism. Deletion of LCAT results in a profound HDL deficiency in both male and female mice (Li et al. 2011). However, LCAT-knockout female mice are protected from high-fat high-sucrose diet-induced obesity, but male mutant mice are not (Li et al. 2011). The most striking sexually dimorphic pattern was found in mice lacking the cytokine IL-6 in the muscle. On one hand, deletion of IL- 6 from the muscle results in decreased body weight in male mice, which is associated with lower core body temperature during the light phase and increased respiratory exchange ratio (Ferrer et al. 2014, Molinero et al. 2017). On the other hand, loss of IL-6 in female muscles leads to increased body weight (Ferrer et al. 2014, Molinero et al. 2017). Thus, IL-6 in the muscle regulates energy balance in exactly opposite directions in males vs females.

Together, these findings indicate that many autosome genes contribute to the sex differences in energy balance through multiple mechanisms. Conceivably, 
some factors/genes may be transcriptional targets of sex hormones, since estrogens, protesterone and androgens are all known to regulate gene expression via their nuclear receptors. Alternatively, some factors/molecules may mediate body weight-regulatory effects of the sex hormones, e.g. STAT3 being a mediator of anorexigenic effects of estrogens. Further, some factors could regulate levels of sex hormones or receptors, e.g. KISS1-GPR54 and AT2R. Of course, some genes may be independent of sex hormone actions and function as parallel mechanisms to mediate sex differences in energy balance, e.g. TAp63. Of course, how these factors functionally interact with the sex hormones/chromosomes remain largely unknown and future studies are certainly warranted. It also needs to be pointed out that a lot more factors/molecules in this category may exist but are missed simply because female animals are purposely avoided in most studies to reduce efforts.

\section{Conclusions}

The existence of sex difference in biology and physiology, including the energy homeostasis, has been increasingly appreciated (Arnold 2014), and the underlying mechanisms started to emerge (Fig. 1). The sex chromosomes are the

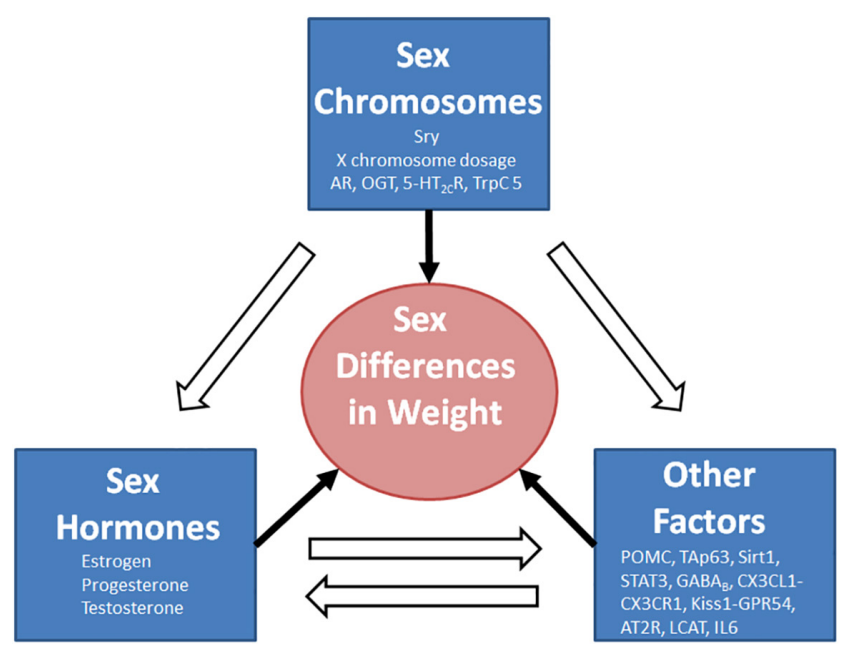

Figure 1

A proposed framework for molecular mechanisms underlying sex differences in body weight control. The Sry gene in the Y chromosome determines gonadal development and therefore the levels of sex hormones. The $X$ chromosome dosage adds the risk of obesity in females; some X-linked genes have been implicated in the regulation of energy balance. Sex hormones are involved in the regulation of body weight balance in both sexes. In addition, other factors (autosome-encoded factors that are not sex hormones/receptors) contribute to the sex differences in body weight control. These three categories of factors are integrated through their reciprocal interactions to ultimately determine the sex differences in body weight balance. fundamental difference between males and females and genes in the $\mathrm{X}$ or $\mathrm{Y}$ chromosome are conceivably major contributors to the sexual dimorphism. The Sry gene in the $\mathrm{Y}$ chromosome determines the fate of gonadal development, and therefore, influence the levels of sex hormones. The $\mathrm{X}$ chromosome dosage adds the risk of obesity in females with mechanisms that are yet to unfold; in parallel, some X-linked genes, including those encoding the androgen receptor, OGT, 5-HT2CR, TRPC5, and likely more, are involved in the regulation of energy balance, and some of these molecules are therapeutic targets for obesity treatment. All sex hormones, including estrogens, progesterone and androgens, are involved in the regulation of body weight balance in both sexes, but their actions and mechanisms are largely sex specific. In addition, increasing number of autosome genes are found to contribute to the sex differences in body weight control. While some of these genes are either downstream targets or upstream factors of sex hormones, some of them appear to provide parallel mechanisms and function independent of the hormones.

Despite the expanding list of factors found to be involved in sex differences in body weight control, and an emerging framework where these factors and signals may be integrated to regulate energy homeostasis in different sexes, a number of areas need further investigations. First, for any tissues or cells that can regulate energy balance, their functions in different sexes would depend on the strength of estrogenic or androgenic tone locally in that region, which is ultimately determined by the availability of the sex hormones, the aromatase activity and the relevant receptors. Thus, a few important questions need to be systemically addressed. Are these factors (sex hormones, aromatase and the receptors) present in metabolic organs (including body weight-regulatory brain regions) in each sex? Are their levels dynamic throughout the life period? Most importantly, what are their functions in the context of energy balance? In addition, given the established role of the $\mathrm{X}$ chromosome dosage in body weight control, efforts are needed to identify what X-linked genes regulate energy balance and to determine whether these genes regulate body weight only in females, males or both. Further, we predict that a large number of other factors, not directly related to sex hormones/receptors and not encoded by sex chromosomes, also contribute to the sex differences in energy balance. Therefore, we call attention to these 'other factors' as potential regulators of sex differences in energy balance. Pharmacological and genetic investigations into energy balance in animal models are warranted and should contrast males with 
females, as required by the funding agencies, e.g. the NIH (Tannenbaum et al. 2016). After these factors are identified, new studies can be designed to further delineate how they interact with sex hormones as well as sex-linked genes.

\section{Declaration of interest}

The authors declare that there is no conflict of interest that could be perceived as prejudicing the impartiality of this review.

\section{Acknowledgements}

This work was supported by grants from the NIH (R01DK115761, R01DK101379, R01DK117281 and P01DK113954 to $Y X U$ ), USDA/CRIS (3092-5-001-059 to $\mathrm{Y} \mathrm{Xu}$ ) and American Heart Association awards (17GRNT32960003 to Y Xu; 16POST27260254 to C Wang).

\section{References}

Alexiou E, Hatziagelaki E, Pergialiotis V, Chrelias C, Kassanos D, Siristatidis C, Kyrkou G, Kreatsa M \& Trakakis E 2017 Hyperandrogenemia in women with polycystic ovary syndrome: prevalence, characteristics and association with body mass index. Hormone Molecular Biology and Clinical Investigation 29 105-111. (https://doi.org/10.1515/hmbci-2016-0047)

Amateau SK, Alt JJ, Stamps CL \& McCarthy MM 2004 Brain estradiol content in newborn rats: sex differences, regional heterogeneity, and possible de novo synthesis by the female telencephalon.

Endocrinology 145 2906-2917. (https://doi.org/10.1210/en.2003-1363)

Arnold AP 2014 Conceptual frameworks and mouse models for studying sex differences in physiology and disease: why compensation changes the game. Experimental Neurology 259 2-9. (https://doi. org/10.1016/j.expneurol.2014.01.021)

Asarian L \& Geary N 2007 Estradiol enhances cholecystokinindependent lipid-induced satiation and activates estrogen receptoralpha-expressing cells in the nucleus tractus solitarius of ovariectomized rats. Endocrinology 148 5656-5666. (https://doi. org/10.1210/en.2007-0341)

Benz V, Bloch M, Wardat S, Bohm C, Maurer L, Mahmoodzadeh S, Wiedmer P, Spranger J, Foryst-Ludwig A \& Kintscher U 2012 Sexual dimorphic regulation of body weight dynamics and adipose tissue lipolysis. PLOS ONE 7 e37794. (https://doi.org/10.1371/journal. pone.0037794)

Berglund ED, Liu C, Sohn JW, Liu T, Kim MH, Lee CE, Vianna CR, Williams KW, Xu Y \& Elmquist JK 2013 Serotonin 2C receptors in pro-opiomelanocortin neurons regulate energy and glucose homeostasis. Journal of Clinical Investigation 123 5061-5070. (https:// doi.org/10.1172/JCI70338)

Bruning JC, Gautam D, Burks DJ, Gillette J, Schubert M, Orban PC, Klein R, Krone W, Muller-Wieland D \& Kahn CR 2000 Role of brain insulin receptor in control of body weight and reproduction. Science 289 2122-2125. (https://doi.org/10.1126/science.289.5487.2122)

Butera PC \& Beikirch RJ 1989 Central implants of diluted estradiol: independent effects on ingestive and reproductive behaviors of ovariectomized rats. Brain Research 491 266-273. (https://doi. org/10.1016/0006-8993(89)90062-0)

Butera PC, Willard DM \& Raymond SA 1992 Effects of PVN lesions on the responsiveness of female rats to estradiol. Brain Research $\mathbf{5 7 6}$ 304-310. (https://doi.org/10.1016/0006-8993(92)90694-5)

Callewaert F, Venken K, Ophoff J, De Gendt K, Torcasio A, van Lenthe GH, Van Oosterwyck H, Boonen S, Bouillon R, Verhoeven G, et al. 2009 Differential regulation of bone and body composition in male mice with combined inactivation of androgen and estrogen receptor-alpha. FASEB Journal 23 232-240. (https://doi.org/10.1096/ fj.08-113456)

Cao J \& Patisaul HB 2011 Sexually dimorphic expression of hypothalamic estrogen receptors alpha and beta and Kiss1 in neonatal male and female rats. Journal of Comparative Neurology 519 2954-2977. (https://doi.org/10.1002/cne.22648)

Cao X, Xu P, Oyola MG, Xia Y, Yan X, Saito K, Zou F, Wang C, Yang Y, Hinton A Jr, et al. 2014 Estrogens stimulate serotonin neurons to inhibit binge-like eating in mice. Journal of Clinical Investigation 124 4351-4362. (https://doi.org/10.1172/JCI74726)

Chan L \& O'Malley BW 1976 Mechanism of action of the sex steroid hormones (first of three parts). New England Journal of Medicine 294 1322-1328. (https://doi.org/10.1056/NEJM197606102942405)

Chen X, McClusky R, Chen J, Beaven SW, Tontonoz P, Arnold AP \& Reue K 2012 The number of X chromosomes causes sex differences in adiposity in mice. PLOS Genetics 8 e1002709. (https://doi. org/10.1371/journal.pgen.1002709)

Cisternas CD, Tome K, Caeiro XE, Dadam FM, Garcia-Segura LM \& Cambiasso MJ 2015 Sex chromosome complement determines sex differences in aromatase expression and regulation in the stria terminalis and anterior amygdala of the developing mouse brain. Molecular and Cellular Endocrinology 414 99-110. (https://doi. org/10.1016/j.mce.2015.07.027)

Correa SM, Newstrom DW, Warne JP, Flandin P, Cheung CC, LinMoore AT, Pierce AA, Xu AW, Rubenstein JL \& Ingraham HA 2015 An estrogen-responsive module in the ventromedial hypothalamus selectively drives sex-specific activity in females. Cell Reports $\mathbf{1 0}$ 62-74. (https://doi.org/10.1016/j.celrep.2014.12.011)

Dalmasso C, Amigone JL \& Vivas L 2011 Serotonergic system involvement in the inhibitory action of estrogen on induced sodium appetite in female rats. Physiology and Behavior 104 398-407. (https://doi.org/10.1016/j.physbeh.2011.04.029)

d'Anglemont de Tassigny X, Fagg LA, Dixon JP, Day K, Leitch HG, Hendrick AG, Zahn D, Franceschini I, Caraty A, Carlton MB, et al. 2007 Hypogonadotropic hypogonadism in mice lacking a functional Kiss1 gene. PNAS 104 10714-10719. (https://doi.org/10.1073/ pnas.0704114104)

Davis KE, Carstens EJ, Irani BG, Gent LM, Hahner LM \& Clegg DJ 2014 Sexually dimorphic role of $\mathrm{G}$ protein-coupled estrogen receptor (GPER) in modulating energy homeostasis. Hormones and Behavior 66 196-207. (https://doi.org/10.1016/j.yhbeh.2014.02.004)

de Souza FS, Nasif S, Lopez-Leal R, Levi DH, Low MJ \& Rubinsten M 2011 The estrogen receptor alpha colocalizes with proopiomelanocortin in hypothalamic neurons and binds to a conserved motif present in the neuron-specific enhancer nPE2. European Journal of Pharmacology 660 181-187. (https://doi. org/10.1016/j.ejphar.2010.10.114)

De Vries GJ, Rissman EF, Simerly RB, Yang LY, Scordalakes EM, Auger CJ, Swain A, Lovell-Badge R, Burgoyne PS \& Arnold AP 2002 A model system for study of sex chromosome effects on sexually dimorphic neural and behavioral traits. Journal of Neuroscience 22 9005-9014. (https://doi.org/10.1523/JNEUROSCI.22-20-09005.2002)

Dorfman MD, Krull JE, Douglass JD, Fasnacht R, Lara-Lince F, Meek TH, Shi X, Damian V, Nguyen HT, Matsen ME, et al. 2017 Sex differences in microglial CX3CR1 signalling determine obesity susceptibility in mice. Nature Communications 8 14556. (https://doi.org/10.1038/ ncomms14556)

Drewett RF 1973 Sexual behaviour and sexual motivation in the female rat. Nature 242 476-477. (https://doi.org/10.1038/242476a0)

Dumesic DA, Akopians AL, Madrigal VK, Ramirez E, Margolis DJ, Sarma MK, Thomas AM, Grogan TR, Haykal R, Schooler TA, et al. 2016 Hyperandrogenism accompanies increased intra-abdominal fat storage in normal weight polycystic ovary syndrome women. Journal of Clinical Endocrinology and Metabolism 101 4178-4188. (https://doi. org/10.1210/jc.2016-2586) 
Fagman JB, Wilhelmson AS, Motta BM, Pirazzi C, Alexanderson C, De Gendt K, Verhoeven G, Holmang A, Anesten F, Jansson JO, et al. 2015 The androgen receptor confers protection against dietinduced atherosclerosis, obesity, and dyslipidemia in female mice. FASEB Journal 29 1540-1550. (https://doi.org/10.1096/fj.14259234)

Fan W, Yanase T, Nomura M, Okabe T, Goto K, Sato T, Kawano H, Kato S \& Nawata H 2005 Androgen receptor null male mice develop lateonset obesity caused by decreased energy expenditure and lipolytic activity but show normal insulin sensitivity with high adiponectin secretion. Diabetes 54 1000-1008. (https://doi.org/10.2337/ diabetes.54.4.1000)

Feng Y, Manka D, Wagner KU \& Khan SA 2007 Estrogen receptor-alpha expression in the mammary epithelium is required for ductal and alveolar morphogenesis in mice. PNAS 104 14718-14723. (https:// doi.org/10.1073/pnas.0706933104)

Ferrer B, Navia B, Giralt M, Comes G, Carrasco J, Molinero A, Quintana A, Senaris RM \& Hidalgo J 2014 Muscle-specific interleukin- 6 deletion influences body weight and body fat in a sexdependent manner. Brain, Behavior, and Immunity 40 121-130. (https://doi.org/10.1016/j.bbi.2014.03.001)

Finan B, Yang B, Ottaway N, Stemmer K, Muller TD, Yi CX, Habegger K, Schriever SC, Garcia-Caceres C, Kabra DG, et al. 2012 Targeted estrogen delivery reverses the metabolic syndrome. Nature Medicine 18 1847-1856. (https://doi.org/10.1038/nm.3009)

Foryst-Ludwig A, Clemenz M, Hohmann S, Hartge M, Sprang C, Frost N, Krikov M, Bhanot S, Barros R, Morani A, et al. 2008 Metabolic actions of estrogen receptor beta (ERbeta) are mediated by a negative cross-talk with PPARgamma. PLOS Genetics 4 e1000108. (https://doi. org/10.1371/journal.pgen.1000108)

Gabory A, Roseboom TJ, Moore T, Moore LG \& Junien C 2013 Placental contribution to the origins of sexual dimorphism in health and diseases: sex chromosomes and epigenetics. Biology of Sex Differences 4 5. (https://doi.org/10.1186/2042-6410-4-5)

Gao Q, Mezei G, Nie Y, Rao Y, Choi CS, Bechmann I, Leranth C, ToranAllerand D, Priest CA, Roberts JL, et al. 2007 Anorectic estrogen mimics leptin's effect on the rewiring of melanocortin cells and Stat3 signaling in obese animals. Nature Medicine 13 89-94. (https:// doi.org/10.1038/nm1525)

Gao Y, Yao T, Deng Z, Sohn JW, Sun J, Huang Y, Kong X, Yu KJ, Wang RT, Chen H, et al. 2017 TrpC5 mediates acute leptin and serotonin effects via POMC neurons. Cell Reports 18 583-592. (https://doi.org/10.1016/j.celrep.2016.12.072)

Geary N, Asarian L, Korach KS, Pfaff DW \& Ogawa S 2001 Deficits in E2-dependent control of feeding, weight gain, and cholecystokinin satiation in ER-alpha null mice. Endocrinology 142 4751-4757. (https://doi.org/10.1210/endo.142.11.8504)

Goodfellow PN \& Lovell-Badge R 1993 SRY and sex determination in mammals. Annual Review of Genetics 27 71-92. (https://doi. org/10.1146/annurev.ge.27.120193.000443)

Grove KL, Fried SK, Greenberg AS, Xiao XQ \& Clegg DJ 2010 A microarray analysis of sexual dimorphism of adipose tissues in highfat-diet-induced obese mice. International Journal of Obesity (Lond) $\mathbf{3 4}$ 989-1000. (https://doi.org/10.1038/ijo.2010.12)

Grove KL \& Smith MS 2003 Ontogeny of the hypothalamic neuropeptide Y system. Physiology and Behavior 79 47-63. (https:// doi.org/10.1016/S0031-9384(03)00104-5)

Grumbach MM \& Auchus RJ 1999 Estrogen: consequences and implications of human mutations in synthesis and action. Journal of Clinical Endocrinology and Metabolism 84 4677-4694. (https://doi. org/10.1210/jcem.84.12.6290)

Haas E, Bhattacharya I, Brailoiu E, Damjanovic M, Brailoiu GC, Gao X, Mueller-Guerre L, Marjon NA, Gut A, Minotti R, et al. 2009 Regulatory role of $\mathrm{G}$ protein-coupled estrogen receptor for vascular function and obesity. Circulation Research 104 288-291. (https://doi. org/10.1161/CIRCRESAHA.108.190892)
Heine PA, Taylor JA, Iwamoto GA, Lubahn DB \& Cooke PS 2000 Increased adipose tissue in male and female estrogen receptor-alpha knockout mice. PNAS 97 12729-12734. (https://doi.org/10.1073/ pnas.97.23.12729)

Hrupka BJ, Smith GP \& Geary N 2002 Hypothalamic implants of dilute estradiol fail to reduce feeding in ovariectomized rats. Physiology and Behavior 77 233-241. (https://doi.org/10.1016/S0031-9384(02)00857-0)

Imai S, Armstrong CM, Kaeberlein M \& Guarente L 2000 Transcriptional silencing and longevity protein Sir2 is an NADdependent histone deacetylase. Nature 403 795-800. (https://doi. org/10.1038/35001622)

Ito Y, Banno R, Shibata M, Adachi K, Hagimoto S, Hagiwara D, Ozawa Y, Goto M, Suga H, Sugimura Y, et al. 2013 GABA type B receptor signaling in proopiomelanocortin neurons protects against obesity, insulin resistance, and hypothalamic inflammation in male mice on a high-fat diet. Journal of Neuroscience 33 17166-17173. (https://doi. org/10.1523/JNEUROSCI.0897-13.2013)

Jarvie BC \& Hentges ST 2012 Expression of GABAergic and glutamatergic phenotypic markers in hypothalamic proopiomelanocortin neurons. Journal of Comparative Neurology 520 3863-3876. (https://doi. org/10.1002/cne.23127)

Johnston CE, Herschel DJ, Lasek AW, Hammer RP Jr \& Nikulina EM 2015 Knockdown of ventral tegmental area mu-opioid receptors in rats prevents effects of social defeat stress: implications for amphetamine cross-sensitization, social avoidance, weight regulation and expression of brain-derived neurotrophic factor. Neuropharmacology 89 325-334. (https://doi.org/10.1016/j. neuropharm.2014.10.010)

Jones ME, Thorburn AW, Britt KL, Hewitt KN, Wreford NG, Proietto J, Oz OK, Leury BJ, Robertson KM, Yao S, et al. 2000 Aromatasedeficient (ArKO) mice have a phenotype of increased adiposity. PNAS 97 12735-12740. (https://doi.org/10.1073/pnas.97.23.12735)

Jorgensen JO, Vahl N, Hansen TB, Fisker S, Hagen C \& Christiansen JS 1996 Influence of growth hormone and androgens on body composition in adults. Hormone Research 45 94-98. (https://doi. org/10.1159/000184766)

Katznelson L, Rosenthal DI, Rosol MS, Anderson EJ, Hayden DL, Schoenfeld DA \& Klibanski A 1998 Using quantitative CT to assess adipose distribution in adult men with acquired hypogonadism. American Journal of Roentgenology 170 423-427. (https://doi. org/10.2214/ajr.170.2.9456958)

Klump KL, Keel PK, Racine SE, Burt SA, Neale M, Sisk CL, Boker S \& $\mathrm{Hu}$ JY 2013 The interactive effects of estrogen and progesterone on changes in emotional eating across the menstrual cycle. Journal of Abnormal Psychology 122 131-137. (https://doi.org/10.1037/ a0029524)

Klump KL, Racine SE, Hildebrandt B, Burt SA, Neale M, Sisk CL, Boker S \& Keel PK 2014 Ovarian hormone influences on dysregulated eating: a comparison of associations in women with versus without binge episodes. Clinical Psychological Science 2 545-559. (https://doi. org/10.1177/2167702614521794)

Komatsu H, Ohara A, Sasaki K, Abe H, Hattori H, Hall FS, Uhl GR \& Sora I 2011 Decreased response to social defeat stress in mu-opioidreceptor knockout mice. Pharmacology, Biochemistry, and Behavior 99 676-682. (https://doi.org/10.1016/j.pbb.2011.06.008)

Kudo T, Konno K, Uchigashima M, Yanagawa Y, Sora I, Minami M \& Watanabe M 2014 GABAergic neurons in the ventral tegmental area receive dual GABA/enkephalin-mediated inhibitory inputs from the bed nucleus of the stria terminalis. European Journal of Neuroscience 39 1796-1809. (https://doi.org/10.1111/ejn.12503)

Lagerlof O, Slocomb JE, Hong I, Aponte Y, Blackshaw S, Hart GW \& Huganir RL 2016 The nutrient sensor OGT in PVN neurons regulates feeding. Science 351 1293-1296. (https://doi.org/10.1126/science. aad5494)

Li L, Hossain MA, Sadat S, Hager L, Liu L, Tam L, Schroer S, Huogen L, Fantus IG, Connelly PW, et al. 2011 Lecithin cholesterol 
acyltransferase null mice are protected from diet-induced obesity and insulin resistance in a gender-specific manner through multiple pathways. Journal of Biological Chemistry 286 17809-17820. (https:// doi.org/10.1074/jbc.M110.180893)

Lin HY, Xu Q, Yeh S, Wang RS, Sparks JD \& Chang C 2005 Insulin and leptin resistance with hyperleptinemia in mice lacking androgen receptor. Diabetes 54 1717-1725. (https://doi.org/10.2337/ diabetes.54.6.1717)

Lin HY, Yu IC, Wang RS, Chen YT, Liu NC, Altuwaijri S, Hsu CL, Ma WL, Jokinen J, Sparks JD, et al. 2008 Increased hepatic steatosis and insulin resistance in mice lacking hepatic androgen receptor. Hepatology 47 1924-1935. (https://doi.org/10.1002/hep.22252)

Liu S, Le May C, Wong WP, Ward RD, Clegg DJ, Marcelli M, Korach KS \& Mauvais-Jarvis F 2009 Importance of extranuclear estrogen receptor-alpha and membrane $\mathrm{G}$ protein-coupled estrogen receptor in pancreatic islet survival. Diabetes 58 2292-2302. (https://doi. org/10.2337/db09-0257)

Malyala A, Zhang C, Bryant DN, Kelly MJ \& Ronnekleiv OK 2008 PI3K signaling effects in hypothalamic neurons mediated by estrogen. Journal of Comparative Neurology 506 895-911. (https://doi. org/10.1002/cne.21584)

Mamounis KJ, Yang JA, Yasrebi A \& Roepke TA 2014 Estrogen response element-independent signaling partially restores post-ovariectomy body weight gain but is not sufficient for 17beta-estradiol's control of energy homeostasis. Steroids $\mathbf{8 1}$ 88-98. (https://doi.org/10.1016/j. steroids.2013.10.018)

Markakis EA 2002 Development of the neuroendocrine hypothalamus. Frontiers in Neuroendocrinology 23 257-291. (https://doi.org/10.1016/ S0091-3022(02)00003-1)

Martensson UE, Salehi SA, Windahl S, Gomez MF, Sward K, DaszkiewiczNilsson J, Wendt A, Andersson N, Hellstrand P, Grande PO, et al. 2009 Deletion of the $\mathrm{G}$ protein-coupled receptor 30 impairs glucose tolerance, reduces bone growth, increases blood pressure, and eliminates estradiol-stimulated insulin release in female mice. Endocrinology 150 687-698. (https://doi.org/10.1210/en.2008-0623)

Martinez de Morentin PB, Gonzalez-Garcia I, Martins L, Lage R, Fernandez-Mallo D, Martinez-Sanchez N, Ruiz-Pino F, Liu J, Morgan DA, Pinilla L, et al. 2014 Estradiol regulates brown adipose tissue thermogenesis via hypothalamic AMPK. Cell Metabolism 20 41-53. (https://doi.org/10.1016/j.cmet.2014.03.031)

Matic M, Bryzgalova G, Gao H, Antonson P, Humire P, Omoto Y, Portwood N, Pramfalk C, Efendic S, Berggren PO, et al. 2013 Estrogen signalling and the metabolic syndrome: targeting the hepatic estrogen receptor alpha action. PLOS ONE 8 e57458. (https:// doi.org/10.1371/journal.pone.0057458)

Matsumoto A \& Arai Y 1980 Sexual dimorphism in 'wiring pattern' in the hypothalamic arcuate nucleus and its modification by neonatal hormonal environment. Brain Research 190 238-242. (https://doi. org/10.1016/0006-8993(80)91173-7)

Mauvais-Jarvis F, Clegg DJ \& Hevener AL 2013 The role of estrogens in control of energy balance and glucose homeostasis. Endocrine Reviews 34 309-338. (https://doi.org/10.1210/er.2012-1055)

McInnes KJ, Smith LB, Hunger NI, Saunders PT, Andrew R \& Walker BR 2012 Deletion of the androgen receptor in adipose tissue in male mice elevates retinol binding protein 4 and reveals independent effects on visceral fat mass and on glucose homeostasis. Diabetes 61 1072-1081. (https://doi.org/10.2337/db11-1136)

McNay DE, Briancon N, Kokoeva MV, Maratos-Flier E \& Flier JS 2011 Remodeling of the arcuate nucleus energy-balance circuit is inhibited in obese mice. Journal of Clinical Investigation 122 142-152. (https:// doi.org/10.1172/JCI43134)

Merchenthaler I, Lane MV, Numan S \& Dellovade TL 2004 Distribution of estrogen receptor alpha and beta in the mouse central nervous system: in vivo autoradiographic and immunocytochemical analyses. Journal of Comparative Neurology 473 270-291. (https://doi. org/10.1002/cne.20128)
Michan S \& Sinclair D 2007 Sirtuins in mammals: insights into their biological function. Biochemical Journal 404 1-13. (https://doi. org/10.1042/BJ20070140)

Miller MM, Tousignant P, Yang U, Pedvis S \& Billiar RB 1995 Effects of age and long-term ovariectomy on the estrogen-receptor containing subpopulations of beta-endorphin-immunoreactive neurons in the arcuate nucleus of female C57BL/6J mice. Neuroendocrinology $\mathbf{6 1}$ 542-551. (https://doi.org/10.1159/000126878)

Molinero A, Fernandez-Perez A, Mogas A, Giralt M, Comes G, Fernandez-Gayol O, Vallejo M \& Hidalgo J 2017 Role of muscle IL-6 in gender-specific metabolism in mice. PLOS ONE 12 e0173675. (https://doi.org/10.1371/journal.pone.0173675)

Morselli E, Frank AP, Palmer BF, Rodriguez-Navas C, Criollo A \& Clegg DJ 2016 A sexually dimorphic hypothalamic response to chronic high-fat diet consumption. International Journal of Obesity $\mathbf{4 0}$ 206-209. (https://doi.org/10.1038/ijo.2015.114)

Moverare-Skrtic S, Venken K, Andersson N, Lindberg MK, Svensson J, Swanson C, Vanderschueren D, Oscarsson J, Gustafsson JA \& Ohlsson C 2006 Dihydrotestosterone treatment results in obesity and altered lipid metabolism in orchidectomized mice. Obesity $\mathbf{1 4}$ 662-672. (https://doi.org/10.1038/oby.2006.75)

Mullican SE, Tomaru T, Gaddis CA, Peed LC, Sundaram A \& Lazar MA 2013 A novel adipose-specific gene deletion model demonstrates potential pitfalls of existing methods. Molecular Endocrinology 27 127-134. (https://doi.org/10.1210/me.2012-1267)

Murphy KG 2005 Kisspeptins: regulators of metastasis and the hypothalamic-pituitary-gonadal axis. Journal of Neuroendocrinology $\mathbf{1 7}$ 519-525. (https://doi.org/10.1111/j.1365-2826.2005.01328.x)

Musatov S, Chen W, Pfaff DW, Mobbs CV, Yang XJ, Clegg DJ, Kaplitt MG \& Ogawa S 2007 Silencing of estrogen receptor alpha in the ventromedial nucleus of hypothalamus leads to metabolic syndrome. PNAS 104 2501-2506. (https://doi.org/10.1073/ pnas.0610787104)

Nelson LR \& Bulun SE 2001 Estrogen production and action. Journal of the American Academy of Dermatology 45 S116-124. (https://doi. org $/ 10.1067 / \mathrm{mjd} .2001 .117432$ )

Nohara K, Zhang Y, Waraich RS, Laque A, Tiano JP, Tong J, Munzberg H \& Mauvais-Jarvis F 2011 Early-life exposure to testosterone programs the hypothalamic melanocortin system. Endocrinology 152 1661-1669. (https://doi.org/10.1210/en.2010-1288)

Nohara K, Liu S, Meyers MS, Waget A, Ferron M, Karsenty G, Burcelin R \& Mauvais-Jarvis F 2013a Developmental androgen excess disrupts reproduction and energy homeostasis in adult male mice. Journal of Endocrinology 219 259-268. (https://doi.org/10.1530/JOE-13-0230)

Nohara K, Waraich RS, Liu S, Ferron M, Waget A, Meyers MS, Karsenty G, Burcelin R \& Mauvais-Jarvis F 2013b Developmental androgen excess programs sympathetic tone and adipose tissue dysfunction and predisposes to a cardiometabolic syndrome in female mice. American Journal of Physiology. Endocrinology and Metabolism 304 E1321-E1330. (https://doi.org/10.1152/ ajpendo.00620.2012)

Nohara K, Laque A, Allard C, Munzberg H \& Mauvais-Jarvis F 2014 Central mechanisms of adiposity in adult female mice with androgen excess. Obesity 22 1477-1484. (https://doi.org/10.1002/ oby.20719)

Nonogaki K, Strack AM, Dallman MF \& Tecott LH 1998 Leptinindependent hyperphagia and type 2 diabetes in mice with a mutated serotonin 5-HT2C receptor gene. Nature Medicine 4 1152-1156. (https://doi.org/10.1038/2647)

Ohlsson C, Hellberg N, Parini P, Vidal O, Bohlooly YM, Rudling M, Lindberg MK, Warner M, Angelin B \& Gustafsson JA 2000 Obesity and disturbed lipoprotein profile in estrogen receptor-alpha-deficient male mice. Biochemical and Biophysical Research Communications 278 640-645. (https://doi.org/10.1006/bbrc.2000.3827)

Kyi-Tha-Thu C, Okoshi K, Ito H, Matsuda K, Kawata M \& Tsukahara S 2015 Sex differences in cells expressing green fluorescent protein 
under the control of the estrogen receptor-alpha promoter in the hypothalamus of mice. Neuroscience Research 101 44-52. (https://doi. org/10.1016/j.neures.2015.07.006)

Okura T, Koda M, Ando F, Niino N, Ohta S \& Shimokata H 2003 Association of polymorphisms in the estrogen receptor alpha gene with body fat distribution. International Journal of Obesity and Related Metabolic Disorders 27 1020-1027. (https://doi.org/10.1038/sj. ijo.0802378)

Ophoff J, Van Proeyen K, Callewaert F, De Gendt K, De Bock K, Vanden Bosch A, Verhoeven G, Hespel P \& Vanderschueren D 2009 Androgen signaling in myocytes contributes to the maintenance of muscle mass and fiber type regulation but not to muscle strength or fatigue. Endocrinology 150 3558-3566. (https://doi.org/10.1210/ en.2008-1509)

Osterlund M, Kuiper GG, Gustafsson JA \& Hurd YL 1998 Differential distribution and regulation of estrogen receptor-alpha and -beta mRNA within the female rat brain. Brain Research. Molecular Brain Research 54 175-180. (https://doi.org/10.1016/S0169328X(97)00351-3)

Otto C, Fuchs I, Kauselmann G, Kern H, Zevnik B, Andreasen P, Schwarz G, Altmann H, Klewer M, Schoor M, et al. 2009 GPR30 does not mediate estrogenic responses in reproductive organs in mice. Biology of Reproduction 80 34-41. (https://doi.org/10.1095/ biolreprod.108.071175)

Palmer K \& Gray JM 1986 Central vs. peripheral effects of estrogen on food intake and lipoprotein lipase activity in ovariectomized rats. Physiology and Behavior 37 187-189. (https://doi.org/10.1016/00319384(86)90404-X)

Pessia E, Makino T, Bailly-Bechet M, McLysaght A \& Marais GA 2012 Mammalian X chromosome inactivation evolved as a dosagecompensation mechanism for dosage-sensitive genes on the $\mathrm{X}$ chromosome. PNAS 109 5346-5351. (https://doi.org/10.1073/ pnas.1116763109)

Qiu J, Fang Y, Ronnekleiv OK \& Kelly MJ 2010 Leptin excites proopiomelanocortin neurons via activation of TRPC channels. Journal of Neuroscience 30 1560-1565. (https://doi.org/10.1523/ JNEUROSCI.4816-09.2010)

Qiu J, Zhang C, Borgquist A, Nestor CC, Smith AW, Bosch MA, Ku S, Wagner EJ, Ronnekleiv OK \& Kelly MJ 2014 Insulin excites anorexigenic proopiomelanocortin neurons via activation of canonical transient receptor potential channels. Cell Metabolism 19 682-693. (https://doi.org/10.1016/j.cmet.2014.03.004)

Qiu J, Bosch MA, Meza C, Navarro UV, Nestor CC, Wagner EJ, Ronnekleiv OK \& Kelly MJ 2018 Estradiol protects proopiomelanocortin neurons against insulin resistance. Endocrinology 159 647-664. (https://doi.org/10.1210/en.2017-00793)

Ramadori G, Fujikawa T, Fukuda M, Anderson J, Morgan DA, Mostoslavsky R, Stuart RC, Perello M, Vianna CR, Nillni EA, et al. 2010 SIRT1 deacetylase in POMC neurons is required for homeostatic defenses against diet-induced obesity. Cell Metabolism 12 78-87. (https://doi.org/10.1016/j.cmet.2010.05.010)

Remmers F \& Delemarre-van de Waal HA 2011 Developmental programming of energy balance and its hypothalamic regulation. Endocrine Reviews 32 272-311. (https://doi.org/10.1210/er.2009-0028)

Reue K 2017 Sex differences in obesity: X chromosome dosage as a risk factor for increased food intake, adiposity and co-morbidities. Physiology and Behaviour 176 174-182. (https://doi.org/10.1016/j. physbeh.2017.02.040)

Reynolds CM, Vickers MH, Harrison CJ, Segovia SA \& Gray C 2015 Maternal high fat and/or salt consumption induces sex-specific inflammatory and nutrient transport in the rat placenta. Physiological Reports 3 e12399. (https://doi.org/10.14814/phy2.12399)

Rhoda J, Corbier P \& Roffi J 1984 Gonadal steroid concentrations in serum and hypothalamus of the rat at birth: aromatization of testosterone to 17 beta-estradiol. Endocrinology 114 1754-1760. (https://doi.org/10.1210/endo-114-5-1754)
Ribas V, Nguyen MT, Henstridge DC, Nguyen AK, Beaven SW, Watt MJ \& Hevener AL 2010 Impaired oxidative metabolism and inflammation are associated with insulin resistance in ERalphadeficient mice. American Journal of Physiology. Endocrinology and Metabolism 298 E304-E319. (https://doi.org/10.1152/ ajpendo.00504.2009)

Rickard DJ, Iwaniec UT, Evans G, Hefferan TE, Hunter JC, Waters KM, Lydon JP, O'Malley BW, Khosla S, Spelsberg TC, et al. 2008 Bone growth and turnover in progesterone receptor knockout mice. Endocrinology 149 2383-2390. (https://doi.org/10.1210/en.2007-1247)

Rinaman L 2006 Ontogeny of hypothalamic-hindbrain feeding control circuits. Developmental Psychobiology 48 389-396. (https://doi. org/10.1002/dev.20146)

Rinaman L 2007 Visceral sensory inputs to the endocrine hypothalamus. Frontiers in Neuroendocrinology 28 50-60. (https://doi.org/10.1016/j. yfrne.2007.02.002)

Robichaud M \& Debonnel G 2005 Oestrogen and testosterone modulate the firing activity of dorsal raphe nucleus serotonergic neurones in both male and female rats. Journal of Neuroendocrinology 17 179-185. (https://doi.org/10.1111/j.1365-2826.2005.01292.x)

Roesch DM 2006 Effects of selective estrogen receptor agonists on food intake and body weight gain in rats. Physiology and Behavior $\mathbf{8 7}$ 39-44. (https://doi.org/10.1016/j.physbeh.2005.08.035)

Rogers NH, Perfield JW, 2nd, Strissel KJ, Obin MS \& Greenberg AS 2009 Reduced energy expenditure and increased inflammation are early events in the development of ovariectomy-induced obesity. Endocrinology 150 2161-2168. (https://doi.org/10.1210/en.20081405)

Rolf C, von Eckardstein S, Koken U \& Nieschlag E 2002 Testosterone substitution of hypogonadal men prevents the age-dependent increases in body mass index, body fat and leptin seen in healthy ageing men: results of a cross-sectional study. European Journal of Endocrinology 146 505-511. (https://doi.org/10.1530/eje.0.1460505)

Ruan HB, Dietrich MO, Liu ZW, Zimmer MR, Li MD, Singh JP, Zhang K, Yin R, Wu J, Horvath TL, et al. 2014 O-GlcNAc transferase enables AgRP neurons to suppress browning of white fat. Cell 159 306-317. (https://doi.org/10.1016/j.cell.2014.09.010)

Saito K, Cao X, He Y \& Xu Y 2015 Progress in the molecular understanding of central regulation of body weight by estrogens. Obesity 23 919-926. (https://doi.org/10.1002/oby.21099)

Samuel P, Khan MA, Nag S, Inagami T \& Hussain T 2013 Angiotensin AT(2) receptor contributes towards gender bias in weight gain. PLOS ONE 8 e48425. (https://doi.org/10.1371/journal.pone.0048425)

Santollo J, Wiley MD \& Eckel LA 2007 Acute activation of ER alpha decreases food intake, meal size, and body weight in ovariectomized rats. American Journal of Physiology Regulatory Integrative and Comparative Physiology 293 R2194-R2201. (https://doi.org/10.1152/ ajpregu.00385.2007)

Santollo J, Torregrossa AM \& Eckel LA 2011 Estradiol acts in the medial preoptic area, arcuate nucleus, and dorsal raphe nucleus to reduce food intake in ovariectomized rats. Hormones and Behavior 60 86-93. (https://doi.org/10.1016/j.yhbeh.2011.03.009)

Sarton E, Teppema LJ, Olievier C, Nieuwenhuijs D, Matthes HW, Kieffer BL \& Dahan A 2001 The involvement of the mu-opioid receptor in ketamine-induced respiratory depression and antinociception. Anesthesia and Analgesia 93 1495-1500. (https://doi. org/10.1097/00000539-200112000-00031)

Sato T, Matsumoto T, Yamada T, Watanabe T, Kawano H \& Kato S 2003 Late onset of obesity in male androgen receptor-deficient (AR KO) mice. Biochemical and Biophysical Research Communications 300 167-171. (https://doi.org/10.1016/S0006-291X(02)02774-2)

Schlenker EH \& Hansen SN 2006 Sex-specific densities of estrogen receptors alpha and beta in the subnuclei of the nucleus tractus solitarius, hypoglossal nucleus and dorsal vagal motor nucleus weanling rats. Brain Research 1123 89-100. (https://doi. org/10.1016/j.brainres.2006.09.035) 
Schumacher M, Guennoun R, Robert F, Carelli C, Gago N, Ghoumari A, Gonzalez Deniselle MC, Gonzalez SL, Ibanez C, Labombarda F, et al. 2004 Local synthesis and dual actions of progesterone in the nervous system: neuroprotection and myelination. Growth Hormone and IGF Research 14(Supplement A) S18-S33. (https://doi. org/10.1016/j.ghir.2004.03.007)

Schwartz SM \& Wade GN 1981 Effects of estradiol and progesterone on food intake, body weight, and carcass adiposity in weanling rats. American Journal of Physiology 240 E499-E503. (https://doi. org/10.1152/ajpendo.1981.240.5.E499)

Seminara SB, Messager S, Chatzidaki EE, Thresher RR, Acierno JS Jr, Shagoury JK, Bo-Abbas Y, Kuohung W, Schwinof KM, Hendrick AG, et al. 2003 The GPR54 gene as a regulator of puberty. New England Journal of Medicine 349 1614-1627. (https://doi.org/10.1056/ NEJMoa035322)

Sharma G, Hu C, Brigman JL, Zhu G, Hathaway HJ \& Prossnitz ER 2013 GPER deficiency in male mice results in insulin resistance, dyslipidemia, and a proinflammatory state. Endocrinology $\mathbf{1 5 4}$ 4136-4145. (https://doi.org/10.1210/en.2013-1357)

Shi H, Seeley RJ \& Clegg DJ 2009 Sexual differences in the control of energy homeostasis. Frontiers in Neuroendocrinology 30 396-404. (https://doi.org/10.1016/j.yfrne.2009.03.004)

Simpson ER 2003 Sources of estrogen and their importance. Journal of Steroid Biochemistry and Molecular Biology 86 225-230. (https://doi. org/10.1016/S0960-0760(03)00360-1)

Smith EP, Boyd J, Frank GR, Takahashi H, Cohen RM, Specker B, Williams TC, Lubahn DB \& Korach KS 1994 Estrogen resistance caused by a mutation in the estrogen-receptor gene in a man. New England Journal of Medicine 331 1056-1061. (https://doi.org/10.1056/ NEJM199410203311604)

Simpson ER, Misso M, Hewitt KN, Hill RA, Boon WC, Jones ME, Kovacic A, Zhou J \& Clyne CD 2005 Estrogen - the good, the bad, and the unexpected. Endocrine Reviews 26 322-330. (https://doi. org/10.1210/er.2004-0020)

Stubbins RE, Holcomb VB, Hong J \& Nunez NP 2012 Estrogen modulates abdominal adiposity and protects female mice from obesity and impaired glucose tolerance. European Journal of Nutrition 51 861-870. (https://doi.org/10.1007/s00394-011-0266-4)

Su X, Gi YJ, Chakravarti D, Chan IL, Zhang A, Xia X, Tsai KY \& Flores ER 2012 TAp63 is a master transcriptional regulator of lipid and glucose metabolism. Cell Metabolism 16 511-525. (https://doi. org/10.1016/j.cmet.2012.09.006)

Sugiyama MG \& Agellon LB 2012 Sex differences in lipid metabolism and metabolic disease risk. Biochemistry and Cell Biology 90 124-141. (https://doi.org/10.1139/o11-067)

Tannenbaum C, Schwarz JM, Clayton JA, de Vries GJ \& Sullivan C 2016 Evaluating sex as a biological variable in preclinical research: the devil in the details. Biology of Sex Differences 7 13. (https://doi. org/10.1186/s13293-016-0066-x)

Tarrade A, Panchenko P, Junien C \& Gabory A 2015 Placental contribution to nutritional programming of health and diseases: epigenetics and sexual dimorphism. Journal of Experimental Biology 218 50-58. (https://doi.org/10.1242/jeb.110320)

Tecott LH, Sun LM, Akana SF, Strack AM, Lowenstein DH, Dallman MF \& Julius D 1995 Eating disorder and epilepsy in mice lacking 5-HT2c serotonin receptors. Nature 374 542-546. (https://doi. org/10.1038/374542a0)

Thomas P, Pang Y, Filardo EJ \& Dong J 2005 Identity of an estrogen membrane receptor coupled to a $G$ protein in human breast cancer cells. Endocrinology 146 624-632. (https://doi.org/10.1210/en.20041064)

Tolson KP, Garcia C, Yen S, Simonds S, Stefanidis A, Lawrence A, Smith JT \& Kauffman AS 2014 Impaired kisspeptin signaling decreases metabolism and promotes glucose intolerance and obesity. Journal of Clinical Investigation 124 3075-3079. (https://doi. org/10.1172/JCI71075)
Tolson KP, Garcia C, Delgado I, Marooki N \& Kauffman AS 2016 Metabolism and energy expenditure, but not feeding or glucose tolerance, are impaired in young Kiss1r KO female mice. Endocrinology 157 4192-4199. (https://doi.org/10.1210/en.20161501)

Toth MJ, Poehlman ET, Matthews DE, Tchernof A \& MacCoss MJ 2001 Effects of estradiol and progesterone on body composition, protein synthesis, and lipoprotein lipase in rats. American Journal of Physiology. Endocrinology and Metabolism 280 E496-501. (https://doi. org/10.1152/ajpendo.2001.280.3.E496)

Vogt MC, Paeger L, Hess S, Steculorum SM, Awazawa M, Hampel B, Neupert S, Nicholls HT, Mauer J, Hausen AC, et al. 2014 Neonatal insulin action impairs hypothalamic neurocircuit formation in response to maternal high-fat feeding. Cell 156 495-509. (https:// doi.org/10.1016/j.cell.2014.01.008)

Wade GN 1975 Some effects of ovarian hormones on food intake and body weight in female rats. Journal of Comparative and Physiological Psychology 88 183-193. (https://doi.org/10.1037/h0076186)

Wallen WJ, Belanger MP \& Wittnich C 2001 Sex hormones and the selective estrogen receptor modulator tamoxifen modulate weekly body weights and food intakes in adolescent and adult rats. Journal of Nutrition 131 2351-2357. (https://doi.org/10.1093/ jn/131.9.2351)

Wang C, Dehghani B, Magrisso IJ, Rick EA, Bonhomme E, Cody DB, Elenich LA, Subramanian S, Murphy SJ, Kelly MJ, et al. 2008 GPR30 contributes to estrogen-induced thymic atrophy. Molecular Endocrinology 22 636-648. (https://doi.org/10.1210/me.2007-0359)

Wang C, He Y, Xu P, Yang Y, Saito K, Xia Y, Yan X, Hinton A Jr, Yan C, Ding H, et al. 2018 TAp63 contributes to sexual dimorphism in POMC neuron functions and energy homeostasis. Nature Communications 9 1544. (https://doi.org/10.1038/s41467-018-03796-7)

Wittmann G, Hrabovszky E \& Lechan RM 2013 Distinct glutamatergic and GABAergic subsets of hypothalamic pro-opiomelanocortin neurons revealed by in situ hybridization in male rats and mice. Journal of Comparative Neurology 521 3287-3302. (https://doi. org/10.1002/cne.23350)

Woodward CJ \& Emery PW 1989 Energy balance in rats given chronic hormone treatment. 2. Effects of corticosterone. British Journal of Nutrition 61 445-452. (https://doi.org/10.1079/BJN19890134)

Wu MV, Manoli DS, Fraser EJ, Coats JK, Tollkuhn J, Honda S, Harada N \& Shah NM 2009 Estrogen masculinizes neural pathways and sexspecific behaviors. Cell 139 61-72. (https://doi.org/10.1016/j. cell.2009.07.036)

Xu AW, Ste-Marie L, Kaelin CB \& Barsh GS 2007 Inactivation of signal transducer and activator of transcription 3 in proopiomelanocortin (Pomc) neurons causes decreased POMC expression, mild obesity, and defects in compensatory refeeding. Endocrinology 148 72-80. (https://doi.org/10.1210/en.2006-1119)

Xu Y, Jones JE, Kohno D, Williams KW, Lee CE, Choi MJ, Anderson JG, Heisler LK, Zigman JM, Lowell BB, et al. 2008 5-HT2CRs expressed by pro-opiomelanocortin neurons regulate energy homeostasis. Neuron 60 582-589. (https://doi.org/10.1016/j.neuron.2008.09.033)

Xu Y, Nedungadi TP, Zhu L, Sobhani N, Irani BG, Davis KE, Zhang X, Zou F, Gent LM, Hahner LD, et al. 2011 Distinct hypothalamic neurons mediate estrogenic effects on energy homeostasis and reproduction. Cell Metabolism 14 453-465. (https://doi.org/10.1016/j. cmet.2011.08.009)

Xu P, Cao X, He Y, Zhu L, Yang Y, Saito K, Wang C, Yan X, Hinton AO $\mathrm{Jr}$, Zou F, et al. 2015 Estrogen receptor-alpha in medial amygdala neurons regulates body weight. Journal of Clinical Investigation 125 2861-2876. (https://doi.org/10.1172/JCI80941)

Xu P, He Y, Cao X, Valencia-Torres L, Yan X, Saito K, Wang C, Yang Y, Hinton A Jr, Zhu L, et al. 2017 Activation of serotonin 2C receptors in dopamine neurons inhibits binge-like eating in mice. Biological Psychiatry 81 737-747. (https://doi.org/10.1016/j. biopsych.2016.06.005) 
Yang CF \& Shah NM 2014 Representing sex in the brain, one module at a time. Neuron 82 261-278. (https://doi.org/10.1016/j. neuron.2014.03.029)

Yang Y, Smith DL Jr, Keating KD, Allison DB \& Nagy TR 2014 Variations in body weight, food intake and body composition after long-term high-fat diet feeding in C57BL/6J mice. Obesity 22 2147-2155. (https://doi.org/10.1002/oby.20811)

Yu IC, Lin HY, Liu NC, Wang RS, Sparks JD, Yeh S \& Chang C 2008 Hyperleptinemia without obesity in male mice lacking androgen receptor in adipose tissue. Endocrinology 149 2361-2368. (https://doi. org/10.1210/en.2007-0516)

Yu Z, Geary N \& Corwin RL 2011 Individual effects of estradiol and progesterone on food intake and body weight in ovariectomized binge rats. Physiology and Behavior 104 687-693. (https://doi. org/10.1016/j.physbeh.2011.07.017)
Yu IC, Lin HY, Liu NC, Sparks JD, Yeh S, Fang LY, Chen L \& Chang C 2013 Neuronal androgen receptor regulates insulin sensitivity via suppression of hypothalamic NF-kappaB-mediated PTP1B expression. Diabetes 62 411-423. (https://doi.org/10.2337/db120135)

Yuan C, Liu X, Mao Y, Diao F, Cui Y \& Liu J 2016 Polycystic ovary syndrome patients with high BMI tend to have functional disorders of androgen excess: a prospective study. Journal of Biomedical Research 30 197-202. (https://doi.org/10.7555/ JBR.30.20140111)

Zhu L, Xu P, Cao X, Yang Y, Hinton AO Jr, Xia Y, Saito K, Yan X, Zou F, Ding H, et al. 2015 The ERalpha-PI3K cascade in proopiomelanocortin progenitor neurons regulates feeding and glucose balance in female mice. Endocrinology 156 4474-4491. (https://doi.org/10.1210/en.2015-1660)

Received in final form 23 August 2018

Accepted 30 August 2018
(C) 2019 Society for Endocrinology Published by Bioscientifica Ltd. Printed in Great Britain 